\section{Tyrosine phosphorylation controls brassinosteroid receptor activation by triggering membrane release of its kinase inhibitor}

\author{
Yvon Jaillais, ${ }^{1,2,4}$ Michael Hothorn, ${ }^{1,4}$ \\ Youssef Belkhadir, ${ }^{1,2,5}$ Tsegaye Dabi, ${ }^{1,2}$ \\ Zachary L. Nimchuk, ${ }^{3}$ Elliot M. Meyerowitz, ${ }^{3}$ \\ and Joanne Chory ${ }^{1,2,6}$

\begin{abstract}
${ }^{1}$ Plant Biology Laboratory, The Salk Institute for Biological Studies, La Jolla, California 92037, USA; ${ }^{2}$ Howard Hughes Medical Institute, The Salk Institute for Biological Studies, La Jolla, California 92037, USA; ${ }^{3}$ Division of Biology 156-29, California Institute of Technology, Pasadena, California 91125, USA
\end{abstract}

Receptor tyrosine kinases control many critical processes in metazoans, but these enzymes appear to be absent in plants. Recently, two Arabidopsis receptor kinases-BRASSINOSTEROID INSENSITIVE 1 (BRI1) and BRI1-ASSOCIATED KINASE1 (BAK1), the receptor and coreceptor for brassinosteroids-were shown to autophosphorylate on tyrosines. However, the cellular roles for tyrosine phosphorylation in plants remain poorly understood. Here, we report that the BRI1 KINASE INHIBITOR 1 (BKI1) is tyrosine phosphorylated in response to brassinosteroid perception. Phosphorylation occurs within a reiterated $[K R][K R]$ membrane targeting motif, releasing BKI1 into the cytosol and enabling formation of an active signaling complex. Our work reveals that tyrosine phosphorylation is a conserved mechanism controlling protein localization in all higher organisms.

Supplemental material is available for this article.

Received October 11, 2010; revised version accepted December 20, 2010.

Plant genomes encode hundreds of receptor kinases that are architecturally related to tyrosine and serine/threonine receptor kinases found in metazoans (Cock et al. 2002). All receptor kinases have a similar molecular architecture, with an extracellular ligand-binding domain, a single transmembrane helix, and a cytoplasmic kinase domain flanked by C-terminal and juxtamembrane regulatory segments (Cock et al. 2002; Lemmon and Schlessinger 2010). The vast majority of receptor kinases in animals

[Keywords: tyrosine phosphorylation; linear motif; plant receptor kinase; brassinosteroid signaling]

${ }^{4}$ These authors contributed equally to this work.

${ }^{5}$ Present address: Biotechnology Development Center, Moroccan Foundation for Advanced Science, Innovation, and Research, Technopolis Rabatshore, Sala al Jadida 11100, Morocco.

${ }^{6}$ Corresponding author.

E-MAIL chory@salk.edu; FAX (858) 558-6379.

Article is online at http://www.genesdev.org/cgi/doi/10.1101/gad.2001911. possess tyrosine kinase activity (58 in humans), while only a few are serine-threonine kinases (12 in humans) (Manning et al. 2002). Receptor tyrosine kinases (RTKs) are involved in many cellular functions, such as proliferation, differentiation, cell survival, and metabolism (Lemmon and Schlessinger 2010; Lim and Pawson 2010). At the molecular level, tyrosine phosphorylation plays diverse roles; e.g., in enzyme activation/deactivation, protein localization, and degradation (Lim and Pawson 2010).

Phylogenetic analyses suggest that receptor kinases have evolved independently in the animal and plant kingdoms (Shiu and Bleecker 2001). Predicted plant receptor kinases fall into a single clade related to the Drosophila cytoplasmic serine/threonine kinase Pelle (Shiu and Bleecker 2001). Importantly, plant genomes do not encode bona fide tyrosine kinases, and therefore tyrosine phosphorylation was thought to be limited to the few known dual-specificity kinases; e.g., GLYCOGEN SYNTHASE KINASE 3 (GSK3) proteins that autophosphorylate on tyrosine (Kim et al. 2009), or MAPKK proteins that phosphorylate MAPK on tyrosine and threonine residues (Mebratu and Tesfaigzi 2009). Two plant receptor kinases involved in brassinosteroid (BR) signaling-BRASSINOSTEROID INSENSITIVE 1 (BRI1) and BRI1-ASSOCIATED KINASE1 (BAK1)-can autophosphorylate on tyrosines, which suggests that tyrosine phosphorylation may not be limited to metazoan signaling (Oh et al. 2009, 2010). Moreover, it was shown recently that autophosphorylation/dephosphorylation of the GSK3-like kinase BRASSINOSTEROID INSENSITIVE2 (BIN2) on Tyr 200 is a critical switch in downstream regulation of BR signaling (Kim et al. 2009).

The BR signaling pathway is one of the best studied in plants (Vert et al. 2005; Belkhadir and Chory 2006). BRI1, the receptor for BRs, is a long-lived protein that cycles between the plasma membrane (PM) and endosomes (Geldner et al. 2007). The kinase is kept in its basal state by the C-terminal tail, which plays an autoinhibitory role, as well as by interactions of BRI1's kinase domain with an inhibitory protein, BRI1 KINASE INHIBITOR 1 (BKI1) (Wang et al. 2005b; Wang and Chory 2006). Binding of brassinolide (BL), the most active BR, in the extracellular domain causes a conformational change in the receptor that leads to autophosphorylation in several domains, including the C-terminal tail (Wang et al. 2005a,b, 2008). BRIl's kinase activity is also necessary for the membrane release of the inhibitory protein BKIl (Wang and Chory 2006).

In an effort to understand the activation mechanism of BRI1 by BRs, we undertook a detailed analysis of BKI1. We show that BKI1 acts through two evolutionarily conserved motifs: a 20-residue conserved segment that binds the BRI1 kinase domain, and a lysine-argininerich motif that targets BKI1 to the PM. Phosphorylation of a key tyrosine within this membrane targeting motif releases BKI1 into the cytosol following ligand perception by BRI1, relieving kinase inhibition and allowing recruitment of BRI1's coreceptor, BAK1. Similar regulatory mechanisms are used to control human RTKs such as the EGF receptor (EGFR), uncovering the convergence of a common regulatory mechanism that controls the activity of membrane-bound kinase receptors. 


\section{Results and Discussion}

\section{Reiterated $[K R][K R]$ doublets form a linear motif required for BKI1 membrane localization}

A key step in BRIl activation is the dissociation of BKI1 from the PM. Although BRI1 is not required for BKI1 association with the PM, our previous studies indicated that BRI1 is required to release BKIl from the PM (Wang and Chory 2006). To understand how BRs control the localization of BKI1, we first asked how BKI1 is targeted to the membrane. BKI1 is an unstructured protein, and as such is likely to function through linear motifs-short sequence patterns involved in protein interactions and/or modifications (Diella et al. 2008). In Arabidopsis root cells, BKI1-mCITRINE was localized to the PM and in the cytosol (Fig. 1B; Supplemental Fig. 1). In contrast, the $\mathrm{N}$-terminal region of BKI1 (BKI1 ${ }^{\mathrm{Nter}}$-mCITRINE, residues 1-265) was localized almost exclusively at the PM (Fig. 1B). Although this region of BKIl is sequence-variable, we identified three conserved motifs in BKI ${ }^{\text {Nter }}$ (motif- 1 to motif-3) (Fig 1A). Various BKI1 ${ }^{\text {Nter }}$ deletions revealed that motif-3 alone was sufficient for PM localization (Fig. 1B; Supplemental Fig. 2). However, unlike BKI1 ${ }^{\text {Nter }}$, it was also associated with endomembrane compartments. Motif-3 contains tandem repeats of basic residues (lysine/ arginine). Additional basic residues are present between motif-2 and motif-3 (Fig. 1A). A BKI1 subdomain that contains four [KR][KR] repeats $\left(\mathrm{BKI} 1^{149-221}\right.$ ) was localized to the PM, like BKI1 ${ }^{\text {Nter }}$ (Fig. 1B). Mutational analysis of full-length BKIl showed that the $[\mathrm{KR}][\mathrm{KR}]$ repeats were required for PM localization (Fig. 1C; Supplemental Figs.

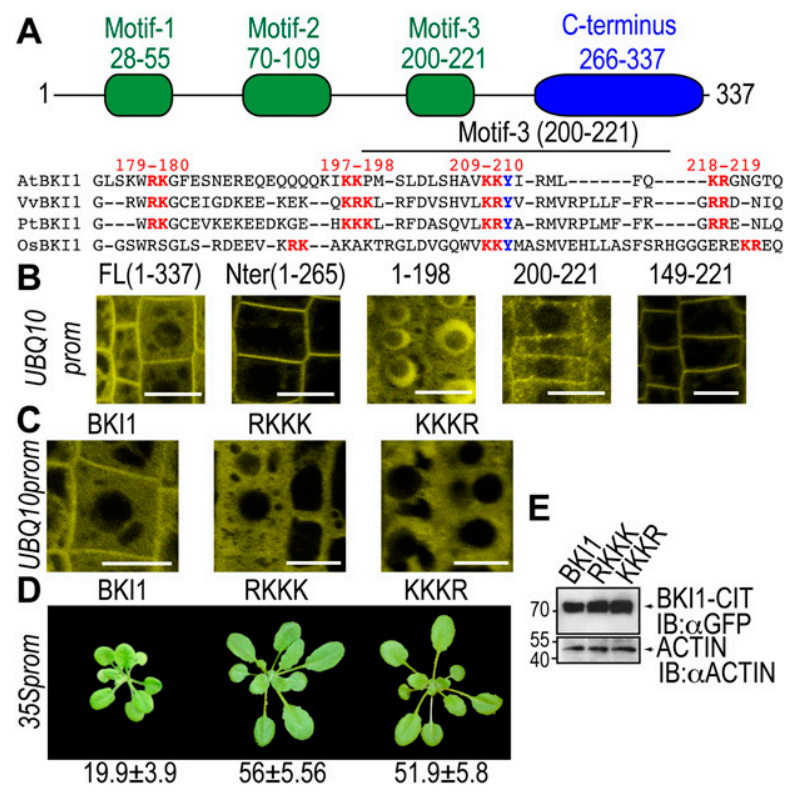

Figure 1. $[\mathrm{KR}][\mathrm{KR}]$ repeats target BKI1 to the PM. (A) Schematic representation of $\mathrm{BKIl}$ conserved regions and alignment between membrane targeting regions of BKIl orthologs. (Red) Doublets of dibasic residues; (blue) Y211. (B) Deletion constructs used to identify the BKIl targeting region. (C) Identification of key residues within the membrane targeting motif required for localization. (RKKK) RK179-180 and KK197-198 mutation into AAAA; (KKKR) KK209210 and KR 218-219 into AAAA. (D) BKI1 gain-of-function phenotype; rosette radius in millimeters $\pm \operatorname{SD}(n=25)$. (E) Expression level of transgenic proteins. Bar $10 \mu \mathrm{m}$.
3 , 4). It is possible that this motif directly recognizes phospholipid head groups or, alternatively, interacts with a PM protein.

Mutations in the $[\mathrm{KR}][\mathrm{KR}]$ motif result in BKIl mutant proteins that are no longer associated with the PM. We next asked whether BKIl can regulate BR signaling when it is not at the PM. Because bki1 loss-of-function mutants are not available and transgenic silencing of BKI1 has a weak phenotype (Wang and Chory 2006), we developed a gain-of-function strategy: Overexpression of BKI1mCITRINE resulted in a semidwarf phenotype, but overexpression of either BKI1 ${ }^{\mathrm{KKKR}}$-mCITRINE or BKI1 ${ }^{\mathrm{RKKK}}$ mCITRINE were indistinguishable from the wild type, despite these proteins being expressed at levels similar to BKI1-mCITRINE (Fig. 1D,E). Thus, we conclude that BKI1 has to be PM-localized to regulate BR signaling.

\section{Release of BKI1 from the PM is triggered by tyrosine phosphorylation}

BKIl is a phosphoprotein in planta and is readily phosphorylated by BRI1-KD (kinase-domain) in vitro (Wang and Chory 2006). Since linear motifs are often posttranslationally modified (Diella et al. 2008), we tested the hypothesis that BRI1 phosphorylates BKI1 ${ }^{\text {Nter }}$ to release it from the PM. Alignment of BKI1 from different species identified a conserved tyrosine (Y211) within motif-3 (Fig. 1A). BRI1 has been reported to autophosphorylate on both serine/threonine as well as tyrosine residues (Oh et al. 2000, 2009; Wang et al. 2005a), but the functional significance of this dual-specificity kinase activity is unclear. Following treatment with BL, the most active BR in Arabidopsis, BKI1 was associated mainly with the soluble fraction, while it accumulated in the microsomal fraction when BR biosynthesis was inhibited by brassinazole (BRZ) (Fig. 2A; Sekimata et al. 2001). Anti-pY (anti-phosphorylated tyrosine) antibodies recognized the soluble pool of BKI1 but not BKI1 associated with microsomes (Fig. 2A). Furthermore, BKI1 was tyrosine phosphorylated only in wild-type plants, but not in a bri1-null mutant (Fig. 2B). To further assess the role of tyrosine phosphorylation of BKI1, we mutated Y211 into phenylalanine (Y211F). BKI1 ${ }^{\mathrm{Y} 211 \mathrm{~F}}$-mCITRINE was not recognized by anti-pY antibodies, suggesting that Y211 is the site of tyrosine phosphorylation in BKI1 (Fig. 2B). Consistently, the recombinant BRI1 kinase domain, but not a catalytically dead mutant version, was able to directly phosphorylate full-length BKI1 in vitro (Fig. 2C).

The nonphosphorylizable BKI1 ${ }^{\mathrm{Y} 211 \mathrm{~F}}$-mCITRINE mutant is constitutively PM-localized and cannot dissociate from the membrane following BL treatment (Fig. 2D). In contrast, the phospho-mimicking BKI1 ${ }^{\text {Y211D }}$-mCITRINE mutant is found in the cytosol in both the presence and absence of BL (Fig. 2D). Overexpression of BKI1 ${ }^{\mathrm{Y} 211 \mathrm{~F}}$ resulted in severely dwarf plants that resembled the overexpression phenotype of myristoylated BKIl (Fig. 2E; Supplemental Fig. 5), which remains associated with the PM even in the presence of BL (Fig. 2D; Wang and Chory 2006). BKI1 ${ }^{\text {Y211D }}$ overexpression caused no aberrant phenotype, consistent with its cytosolic localization (Fig. 2E,F; Supplemental Fig. 5). Altogether, our analyses strongly suggest that, upon BR perception, BRIl phosphorylates BKII on Y211 to displace the kinase inhibitor into the cytosol, where it is inactive. 
Jaillais et al.

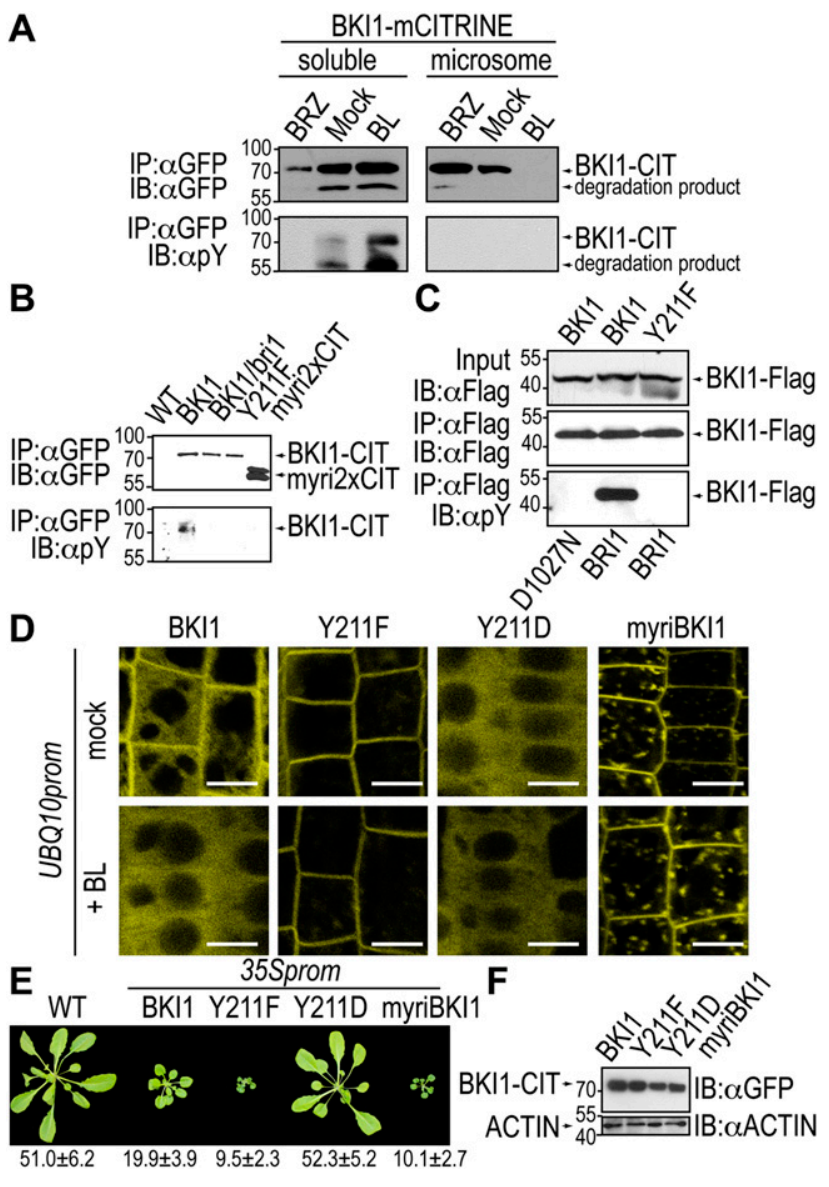

Figure 2. Tyrosine phosphorylation regulates BKI1 membrane localization in response to BRs. $(A, B)$ Immunoprecipitation (IP) of BKI1-mCITRINE with an anti-GFP antibody and immunoblot (IB) using an anti-GFP antibody or anti-phosphotyrosine antibody (pY). (C) Tyrosine phosphorylation of in vitro translated BKI1Flag/BKII Y211F $_{\text {Flag in the presence of BRI1-KD }}^{(814-1196)}$ or BRI1-KD ${ }^{(814-1196)}$ D $1027 \mathrm{~N}$. (D) Subcellular localization and dynamics upon BR treatment of the Y211F and Y211D mutant proteins. Myri designates protein with a myristoylation signal. $(E)$ Overexpression phenotype of BKIl tyrosine mutant proteins compared with wild type and myriBKIl; rosette radius in millimeters $\pm \mathrm{SD}(n=25)$. $(F)$ Expression level of transgenic proteins. Bar $10 \mu \mathrm{m}$.

\section{BKI1's C terminus is a novel kinase-interacting peptide}

We next addressed how BKI1 negatively regulates BRI1 activity. In previous studies, we showed that BKI1 ${ }^{\text {Cter }}$ interacts with the isolated BRIl-KD (Wang and Chory 2006), and BKI1 ${ }^{\text {Cter }}$ is required for causing the BKI1 overexpression phenotype (Fig. 3A,B). To learn more about the molecular determinants that may be involved in BKIl function, we mapped a conserved motif in $\mathrm{BKIl}^{\mathrm{Cter}}$ that we named the BKIl C-terminal tail (BKIlCT residues 306-325) (Supplemental Fig. 6). Isothermal titration calorimetry (ITC) assays revealed that a synthetic $21 \mathrm{mer}$ peptide derived from this motif was sufficient to tightly interact with the isolated BRIl kinase domain $\left(\mathrm{K}_{\mathrm{d}} \approx 2 \mu \mathrm{M}\right)$ with 1:1 stoichiometry (Table 1; Fig. $4 \mathrm{~A})$. Thereafter, we compared the overexpression phenotypes of BKIl-mCITRINE with mutant versions in which we deleted the BRI1 interaction region $\left(\mathrm{BKII}^{\mathrm{Nter}}{ }^{\mathrm{mCCI}}\right.$ TRINE) or mutated it in conserved residues (BKII ${ }^{\mathrm{LQII}}$ -
mCITRINE and BKI1 ${ }^{\mathrm{C} 322 \mathrm{~A}}$-mCITRINE) (see Supplemental Fig. 6 for details of the mutants).

Overexpression of these mutant forms failed to produce a dwarf phenotype (Fig. 3A,B). Wild-type BKIl-mCITRINE and BKI1 $\mathrm{C}^{222 \mathrm{~A}}$-mCITRINE, but not BKII ${ }^{\mathrm{Nter}}$-mCITRINE

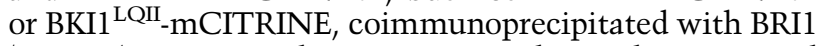
(Fig. 3C). Consistently, mutant peptides in the conserved HCK motif of BKIl-CT interacted with BRI1-KD in ITC experiments, while the LQII mutant peptide did not (Table 1). Altogether, these results indicate that BKI1-CT is required for interaction with BRIl, and further suggest that this interaction is necessary but not sufficient to inhibit BRIl activity in planta. We found that both

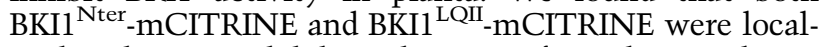
ized at the PM and did not dissociate from the membrane following BL treatment (Fig. 3D). However, BKI1 ${ }^{\mathrm{C} 322 \mathrm{~A}}$ mCITRINE localization was identical to BKIl-mCITRINE (Fig. 3D). Consistently, only wild-type and C322A BKII were tyrosine-phosphorylated, but not BKI1 ${ }^{\text {Nter }}$ or BKI $1^{\text {LQII }}$ (Fig. 3E). Therefore, BKIl interaction with BRIl, but not its inhibitory activity, is required for BKIl localization changes and tyrosine phosphorylation. These results further implicate BKIl as the direct substrate of BRIl kinase in vivo.

\section{BKI1 C-terminal tail binding to BRI1 inhibits interaction with the coreceptor}

We next characterized the mechanism by which BKI1 inhibits BRIl function. The BKI1-CT 21 mer interacted with multiple forms of BRIl kinase in vitro, including wild-type, kinase-dead (BRI1 ${ }^{\text {D1027N }}$ ), or hyperphosphorylated (BRI1 ${ }^{\mathrm{T} 872 \mathrm{~A}}$ ) versions (Table 1; Supplemental Fig. 6). The interaction was independent of the presence of BRI1's C-terminal tail (Table 1; Wang et al. 2005b). The BKIl-CT

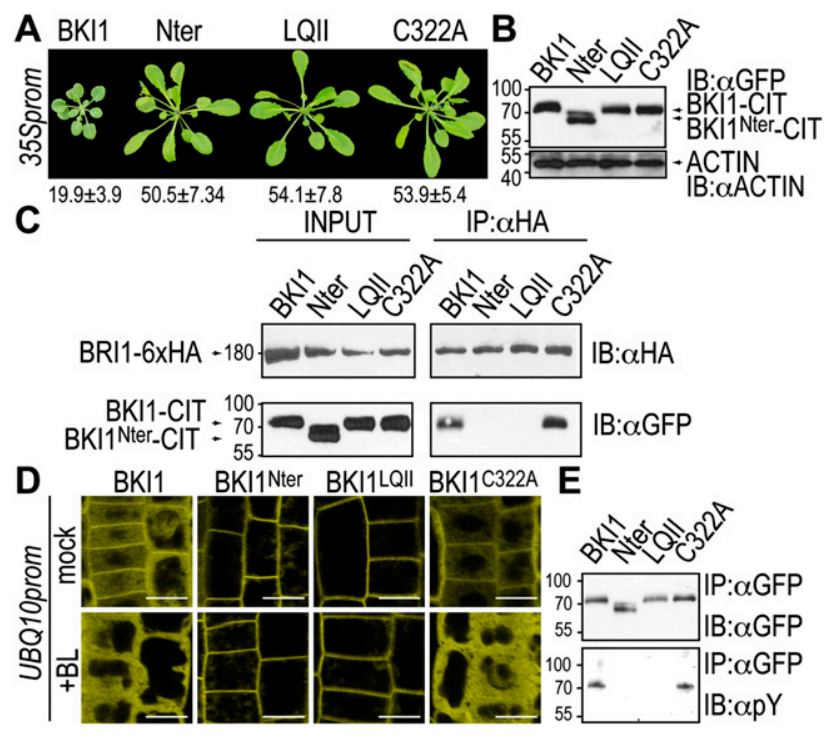

Figure 3. BKI1-CT is required for BRIl interaction and inhibition, and for BKIl phosphorylation. (A) Overexpression phenotype of BKI1-CT deletion or point mutant proteins; rosette radius in millimeters $\pm \mathrm{SD}(n=25)$. $(B)$ Expression level of transgenic proteins. (C) Coimmunoprecipitation of BKIl wild-type and mutant versions with BRI1-6xHA. Localization $(D)$ and tyrosine phosphorylation $(E)$ of BKII-CT mutant proteins compared with wild-type BKI1. Bar $10 \mu \mathrm{m}$. 
Table 1. Interaction between the BRI1 kinase domain and the C-terminal tail of BKI1 and MAKR proteins

\begin{tabular}{|c|c|c|c|}
\hline Cell & Syringe & $\mathrm{K}_{\mathrm{d}}(\mu \mathrm{M})$ & $\mathrm{N}$ \\
\hline BRI1 ${ }^{865-1160}$ wild type & BKII CT & $2.8 \pm 0.3$ & 0.99 \\
\hline $\mathrm{BRI1}^{865-1160} \mathrm{~T} 872 \mathrm{~A}$ & BKI1 CT & $2.5 \pm 0.3$ & 1.09 \\
\hline $\mathrm{BRII}^{865-1160} \mathrm{D} 1027 \mathrm{~N}$ & BKIl CT & $2.3 \pm 0.2$ & 0.99 \\
\hline BRI1 ${ }^{865-1196}$ wild type & BKI1 CT & $2.4 \pm 0.3$ & 1.02 \\
\hline BRI1 ${ }^{856-1196} \mathrm{D} 1027 \mathrm{~N}$ & BKI1 CT & $2.3 \pm 0.2$ & 0.99 \\
\hline $\mathrm{BRI}^{865-1160} \mathrm{D} 1027 \mathrm{~N}$ & ATP & $44.6 \pm 5.8$ & 1.01 \\
\hline $\begin{array}{l}\mathrm{BRI1}^{865-1160} \mathrm{D} 1027 \mathrm{~N}+ \\
5 \times \text { BKI1 CT }\end{array}$ & ATP & $72.0 \pm 4.4$ & 1.03 \\
\hline $\begin{array}{l}\text { BRI1 }^{865-1160} \text { D } 1027 \mathrm{~N}+ \\
\text { S1044D }\end{array}$ & BKI1 CT & $4.1 \pm 0.4$ & 0.97 \\
\hline $\begin{array}{l}\text { BRI1 }^{865-1160} \text { D } 1027 \mathrm{~N}+ \\
\text { S1044D T1045D }\end{array}$ & BKI1 CT & $2.9 \pm 0.3$ & 1.03 \\
\hline $\begin{array}{l}\text { BRI1 }{ }^{865-1160} \text { D } 1027 \mathrm{~N}+ \\
\text { A1104Y L1106E }\end{array}$ & BKII CT & $22.1 \pm 1.9$ & 0.82 \\
\hline $\mathrm{BRL}^{841-1140} \mathrm{D} 1005 \mathrm{~N}$ & BKI1 CT & n.b. & \\
\hline $\mathrm{BAK} 1^{272-566} \mathrm{D} 434 \mathrm{~N}$ & BKI1 CT & n.b. & \\
\hline $\mathrm{BRI1}^{865-1160} \mathrm{D} 1027 \mathrm{~N}$ & BKI1 C332A & $2.3 \pm 0.2$ & 0.97 \\
\hline $\mathrm{BRI1}^{865-1160} \mathrm{D} 1027 \mathrm{~N}$ & BKII AAA & $2.5 \pm 0.5$ & 1.08 \\
\hline $\mathrm{BRI1}^{865-1160} \mathrm{D} 1027 \mathrm{~N}$ & BKI1 LQII & n.b. & \\
\hline $\mathrm{BRI1}^{865-1160} \mathrm{D} 1027 \mathrm{~N}$ & MAKR1 & $18.1 \pm 0.4$ & 0.89 \\
\hline $\begin{array}{l}\text { BRI1 }^{865-1160} \text { D1027N + } \\
\text { A1104Y L1106E }\end{array}$ & MAKR1 & $>500$ & \\
\hline $\mathrm{BAK}^{272-566} \mathrm{D} 434 \mathrm{~N}$ & MAKR1 & n.b. & \\
\hline BRL1 ${ }^{841-1140}$ D1005N & MAKR1 & n.b. & \\
\hline $\mathrm{BRI1}^{865-1160} \mathrm{D} 1027 \mathrm{~N}$ & MAKR3 & n.b. & \\
\hline $\mathrm{BAK} 1^{272-566} \mathrm{D} 434 \mathrm{~N}$ & MAKR3 & n.b. & \\
\hline $\mathrm{BRL}^{841-1140} \mathrm{D} 1005 \mathrm{~N}$ & MAKR3 & n.b. & \\
\hline $\mathrm{BRI1}^{865-1160} \mathrm{D} 1027 \mathrm{~N}$ & MAKR4 & n.b. & \\
\hline BAK1 ${ }^{272-566} \mathrm{D} 434 \mathrm{~N}$ & MAKR4 & n.b. & \\
\hline BRL1 ${ }^{841-1140}$ D $1005 \mathrm{~N}$ & MAKR4 & n.b. & \\
\hline
\end{tabular}

Summary of the ITC experiments. Shown are experimental values \pm fitting error. (n.b.) No binding.

peptide did not compete with the nucleotide substrate for a common binding site, nor did mutations in the activation loop of the kinase affect BKIl binding (Table 1). These observations indicate that BRI1-KD recognizes BKI1-CT independent of its catalytic state (Supplemental Fig. 6).

BKI1-CT specifically binds to BRI1-KD but not the kinase domains of the coreceptor BAK1 or to BRI1-LIKE 1 (BRL1), a BRI1 homolog sharing $70 \%$ sequence identity (Table 1). To fine-map the binding surface of BKI1-CT, we constructed a BRI1 homology model based on the crystal structure of human IRAK4 kinase (Kuglstatter et al. 2007). We found that most sequence differences between BRIl and BRL1 map to the C-lobe of the kinase (Fig. 4B). Next, we systematically substituted BRI1 nonidentical residues in the BRI1 C-lobe with the corresponding residues in BRL1. Using this approach, we found a double mutant (BRI1 ${ }^{\mathrm{AL}-\mathrm{YE}}$ ) (Fig. 4C) that interacted $\sim 10$ times more weakly with BKI1-CT in calorimetry assays (Table 1). These experiments map the interaction site of BKI1 to the C-terminal lobe of BRI1-KD. MIG6, an inhibitor of the EGFR, binds to a similar surface area in EGFR-KD (Zhang et al. 2007). While MIG6 inhibits the activation of an asymmetric dimer in EGFR (Zhang et al. 2006, 2007), BKI1-CT did not prevent dimerization of BRI1-KD (Supplemental Fig. 7). However, we tested whether BKI1-CT can prevent the interaction between BRI1 and BAK1, as reported for the full-length BKIl (Wang and Chory 2006).
We found that BKI1-CT but not the LQII mutated version of the peptide efficiently competed with BAK1 for binding to BRI1 in coimmunoprecipitation experiments (Fig. 4D). Therefore, we propose that BKI1 binding to the distal surface of the C-lobe down-regulates BRIl activity by inhibiting its interaction with its coreceptor, BAK1.

Next, we used the BRIl-interacting C terminus of BKIl as a starting point to uncover other BKIl-like proteins in Arabidopsis. We identified a family of six additional members that contained both the N-terminal and C-terminal linear motifs that we named MAKR (MEMBRANE-ASSOCIATED KINASE REGULATOR) (Supplemental Fig. 8). In vitro, MAKR1-CT-derived peptide binds to the BRI1-KD $\left(\mathrm{K}_{\mathrm{d}} \approx 18 \mu \mathrm{M}\right)$ (Fig. 4A), and this interaction was significantly decreased when using BRI1 ${ }^{\mathrm{AL}-\mathrm{YE}}$ $\left(\mathrm{K}_{\mathrm{d}}>500 \mu \mathrm{M}\right)$ (Table 1). Moreover, overexpression of MAKR1 had a phenotype similar to overexpression of BKI1 (Fig. 4E). These results suggest that MAKR1, like BKI1, binds to the C-lobe of BRI1-KD and negatively regulates $\mathrm{BR}$ signaling. In contrast, we could not detect an interaction of MAKR3 or MAKR4-CT with BRI1-KD

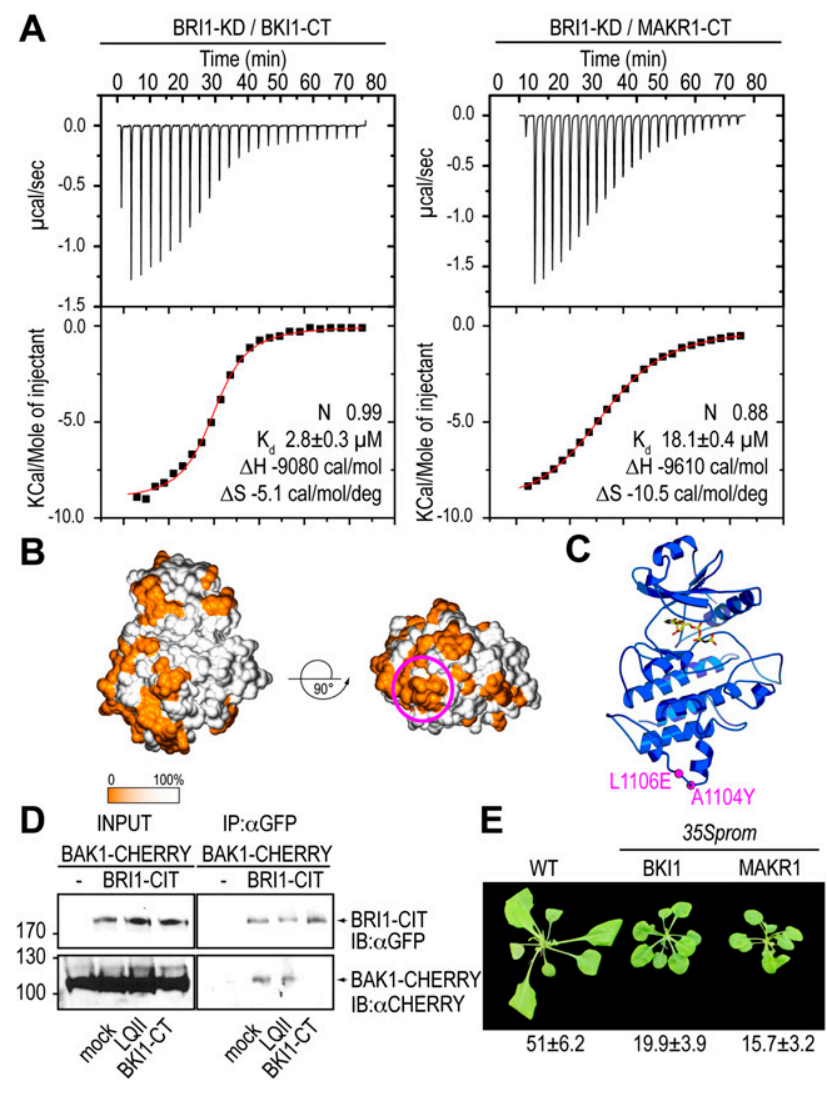

Figure 4. Mechanism of BRI1 inhibition by the BKI1 C-terminal tail. (A) ITC of BRI1-KD ${ }^{(865-1160)}$ versus BKI1-CT, and BRI1-KD ${ }^{(865-1160)}$ D1027N versus MAKR1-CT. Shown are experimental values \pm fitting errors. $(B)$ Sequence divergence between BRI1 and BRL1 mapped onto the molecular surface of a BRIl homology model. Surfaces are colored according to sequence conservation, orange to white for variable to invariant residues. (C) Ribbon diagram of the BRIl homology model depicting the position of the nucleotide (in bond representations) and the C-lobe mutations (in magenta). (D) Coimmunoprecipitation of BAK1-mCHERRY with BRI1-mCITRINE in the presence of $20 \mu \mathrm{M}$ BKI1-CT peptide, LQII peptide, or buffer. $(E)$ MAKR1 gain-of-function phenotype; rosette radius in millimeters $\pm \operatorname{SD}(n=25)$. 
in vitro (Table 1), and their overexpression did not result in a BR-related phenotype (data not shown). Thus, other members of the MAKR family may regulate distinct signaling pathways. Negative regulation by unstructured inhibitor proteins could therefore be a fine-tuning mechanism for several plant receptor kinases.

Functional studies have revealed fundamental differences between receptor kinase signaling in plants and animals, particularly concerning their interaction with downstream partners (Cock et al. 2002). However, the dual specificity kinase BRIl shares common regulatory mechanisms with both tyrosine and serine/threonine receptor kinases, such as trans-phosphorylation of kinases (Wang et al. 2005a, 2008), endosomal signaling (Geldner et al. 2007), a C-terminal regulatory tail (Wang et al. 2005b), and the existence of inhibitory proteins. Given the phylogenetic relationship between receptor kinases in the two kingdoms, these similarities are of particular interest because they may represent evolved solutions that converge on the same fundamental molecular mechanism. This is particularly relevant when unrelated proteins mediate similar regulatory functions, such as BKI1 and MIG6. Thus, determining common features in plant and animal receptor kinase pathways may define the minimum requirements for a robust signaling system.

\section{Materials and methods}

\section{Confocal microscopy, hormone, and inhibitor treatments}

Microscopy and drug treatments were performed as described (Jaillais et al. 2006). Confocal microscopy was done with a Leica SP/2 inverted microscope, and image analysis was performed as described (Jaillais et al. 2007). BL (Chemiclones, $1 \mathrm{mM}$ stock in DMSO) was used at $1 \mu \mathrm{M}$ or as indicated, and treatments were done $5 \mathrm{~min}$ prior to observation or extraction. BRZ (Chemiclones, $10 \mathrm{mM}$ stock in DMSO) was used at $5 \mu \mathrm{M}$ and was supplied into the agar medium.

\section{Protein extraction from plants and immunoprecipitation}

Monoclonal anti-GFP HRP-coupled (Miltenyi Biotech) (mCITRINE is recognized by anti-GFP), anti-pY HRP-coupled (4G10, Millipore), antiHA HRP-coupled (Miltenyi Biotech), anti-ACTIN (clone C4, MP Biomedicals), and anti-Flag (Sigma) were used at 1:5000. All immunoprecipitations were performed as described (Jaillais et al. 2007). Approximately $100 \mathrm{mg}$ of 7-d-old light-grown seedlings were harvested for Western blot experiments. Immunoprecipitation experiments required 1-3 g of seedlings. Tissues were ground at $4^{\circ} \mathrm{C}$ in a $15-\mathrm{mL}$ tube containing $2 \mathrm{~mL}$ of icecold sucrose buffer $(20 \mathrm{mM}$ Tris at $\mathrm{pH} 8,0.33 \mathrm{M}$ sucrose, $1 \mathrm{mM}$ EDTA at $\mathrm{pH} 8$, protease inhibitors [Roche], phosphatase inhibitors [phosSTOP, Roche]) using a polytron (Brinkman). Samples were centrifuged at $5000 \mathrm{~g}$ for $10 \mathrm{~min}$ at $4^{\circ} \mathrm{C}$ or until the supernatants were clear. The resulting extracts corresponded to the total protein fraction. These fractions were used to estimate the accumulation of BKIl mutant proteins compared with wild-type BKIl-mCITRINE. Total protein was quantified and equal amounts were loaded on a SDS-PAGE gel. For cellular fractionation, total protein fractions were centrifuged at $20,000 \mathrm{~g}$ for $45 \mathrm{~min}$ at $4^{\circ} \mathrm{C}$ to pellet microsomes. The resulting supernatant fractions corresponded to the fraction enriched in soluble proteins. The pellet was resuspended in $1 \mathrm{~mL}$ of immunoprecipitation buffer $(50 \mathrm{mM}$ Tris at $\mathrm{pH} 8,150 \mathrm{mM} \mathrm{NaCl}$, $1 \%$ Triton X-100) using a 2-mL potter (Wheaton), and was left on a rotating wheel for $30 \mathrm{~min}$ at $4^{\circ} \mathrm{C}$. Samples were then pelleted at $20,000 \mathrm{~g}$ for $10 \mathrm{~min}$ at $4^{\circ} \mathrm{C}$. The supernatant corresponded to the fraction enriched in microsomal-associated proteins. The proteins in each fraction were quantified and immunoprecipitations were performed on $1 \mathrm{mg}$ of proteins. BRIl immunoprecipitations were performed on the microsomal fraction. For BKIl immunoprecipitations, proteins were extracted directly in immunoprecipitation buffer except when noted otherwise. For the com- petition experiment (Fig. 4D) the membrane fraction was resuspended in immunoprecipitation buffer without Triton and each peptide was added at $20 \mu \mathrm{M}$ final concentration. The mock control is a buffer-only control (ITC buffer) (see below). The samples were incubated on a rotating wheel for $30 \mathrm{~min}$ at $4{ }^{\circ} \mathrm{C}$, then Triton X-100 was added at a $1 \%$ final concentration, and samples were incubated for an additional $30 \mathrm{~min}$ on ice. Samples were then centrifuged at $20,000 \mathrm{~g}$ for $10 \mathrm{~min}$ at $4^{\circ} \mathrm{C}$, and the coimmunoprecipitations were performed on the supernatant.

\section{Recombinant protein expression and purification}

Domain constructs covering the minimal catalytic domains of BRIl, BRL1, and BAK1 were identified using structure-based sequence alignments against the human IRAK4 (PDB-ID 2OID) (Kuglstatter et al. 2007) and tomato Pto (PDB-ID 2QKW) kinases (Xing et al. 2007) using the program EXPRESSO (http://www.tcoffee.org). The resulting kinase domain fragments were cloned into vector pETM11, providing an $\mathrm{N}$-terminal $6 \mathrm{xHis}$ tag and a tobacco etch virus protease (TEV) site. Protein expression in Escherichia coli BL21 (DE3) RIL to $\mathrm{OD}_{600 \mathrm{~nm}}=0.6$ was induced with $0.5 \mathrm{mM}$ ispropyl $\beta$-D-galactoside in terrific broth for $16 \mathrm{~h}$ at $16^{\circ} \mathrm{C}$. Cells were collected by centrifugation at $4500 \mathrm{~g}$ for $30 \mathrm{~min}$, washed in PBS buffer, incubated with $100 \mathrm{mg}$ of lysozyme for $1 \mathrm{~h}$ at room temperature, and snap-frozen in liquid nitrogen. For protein purification, cells were thawed in lysis buffer $(25 \mathrm{mM}$ Tris at $\mathrm{pH} 7.6,500 \mathrm{mM} \mathrm{NaCl}$, $5 \mathrm{mM}$ 2-mercaptoethanol [ $\beta-\mathrm{ME}]$, lysed by sonication, and centrifuged at 75,000 g for $90 \mathrm{~min}$. The supernatant was loaded onto a $\mathrm{Co}^{2+}$ affinity column (HIS-Select Cobalt Affinity Gel, Sigma); washed with $25 \mathrm{mM}$ Tris $(\mathrm{pH} 7.6), 1 \mathrm{M} \mathrm{NaCl}$, and $5 \mathrm{mM} \beta-\mathrm{ME}$; and eluted in lysis buffer supplemented with $200 \mathrm{mM}$ imidazole. The $6 x$ His tag was cleaved with TEV for $16 \mathrm{~h}$ at $4^{\circ} \mathrm{C}$ during dialysis against lysis buffer. The kinase domain was further purified by a second $\mathrm{Co}^{2+}$ affinity step and gel filtration on a Superdex 75 HR26/60 column (GE Healthcare), and was equilibrated in $25 \mathrm{mM}$ Tris (pH 7.2), $250 \mathrm{mM} \mathrm{NaCl}$, and $5 \mathrm{mM} \beta$-ME. Peak fractions were dialyzed against ITC buffer (see below) and remained stable for 3-5 d on ice. Site-specific mutations were introduced by PCR and purified like wild-type proteins. We found that previously employed K911E and K911R kinase-dead (Wang et al. 2008) mutations destabilize the protein in ITC assays and thus generated a different kinase-dead mutation in BRI1 $(\mathrm{D} 1027 \mathrm{~N}), \mathrm{BAK} 1(\mathrm{D} 434 \mathrm{~N})$, and BRL1 (D1005N) as described previously (Bayliss et al. 2003).

\section{ITC}

ITC was performed using an ITC $_{200}$ calorimeter (Microcal). All peptides were synthesized with a tyrosine residue added to their $\mathrm{C}$ terminus to determine peptide concentrations. All proteins were dialyzed extensively against ITC buffer $(50 \mathrm{mM}$ HEPES at $\mathrm{pH} 8.0,250 \mathrm{mM} \mathrm{NaCl}, 1 \%$ glycerol, 1 mM EDTA, $0.5 \mathrm{mM}$ Tris[2-carboxyethyl]phosphine) prior to all titrations. The experiments were performed at $25^{\circ} \mathrm{C}$. A typical titration consisted of injecting $1.6-\mu \mathrm{L}$ aliquots of peptide $(1.5 \mathrm{mM})$ into $150 \mu \mathrm{M}$ protein solution at time intervals of $90 \mathrm{sec}$ to ensure that the titration peak returned to the baseline. ITC data were corrected for the heat of dilution by subtracting the mixing enthalpies for titrant solution injections into protein-free buffer. ITC data were analyzed using the program Origin (version 7.0) as provided by the manufacturer. We used a single set of identical binding site models. Experiments were repeated twice, and lack of binding results were validated with independent protein preparations. For the competition experiments, $150 \mu \mathrm{M}$ kinase domain was incubated with a $5 \times$ molar access of BKI1-CT peptide and was provided in the cell before titrating in nucleotide solution at $1.5 \mathrm{mM}$.

\section{In vitro kinase assay}

Full-length BKI1 and BKI1 ${ }^{\mathrm{Y} 211 \mathrm{~F}}$ tagged with a Flag tag at their C termini were transcribed using the $\mathrm{T} 7$ promoter and were translated in vitro in rabbit reticulocyte lysates as described by the manufacturer (TNT, Promega). The phosphorylation reactions were carried out for $1 \mathrm{~h}$ at $25^{\circ} \mathrm{C}$ in $(25 \mathrm{mM}$ Tris at $\mathrm{pH} 7.5,50 \mathrm{mM} \mathrm{NaCl}, 0.5 \mathrm{mM}$ TCEP, $10 \mathrm{mM}$ $\mathrm{MgCl}_{2}, 0.1 \mathrm{mM}$ ATP) with $10 \mu \mathrm{g}$ of BKIl-Flag proteins and $1 \mu \mathrm{g}$ of freshly purified full-length BRIl kinase domain (residues 814-1196 and either wild-type or including the kinase-dead mutation D1027N, as described above). The reaction was then incubated for an additional $30 \mathrm{~min}$ at $25^{\circ} \mathrm{C}$ 
with BKII C-terminal peptide at $20 \mu \mathrm{M}$ final concentration to dissociate the BKII/BRI1-KD complex. BKI1-Flag was immunoprecipitated for $1 \mathrm{~h}$ at $4^{\circ} \mathrm{C}$ in the presence of $50 \mu \mathrm{L}$ of anti-Flag beads (M2, Sigma), washed four times, and eluted by competition with a Flag peptide (Sigma).

\section{Acknowledgments}

We thank T. Hunter and J. Meisenhelder for helpful discussions, W. Chen for technical assistance, J. Meisenhelder for designing and synthesizing peptides, and M. Dreux and U. Pedmale for providing feedback on the manuscript. The Max Planck society and SALK Institute provided insertion mutant lines, N. Geldner provided the vector pNIGEL, J. Long provided the vector $\mathrm{pB}$ 336, K. Nito provided the vector TNT-Flag, R. Tsien provided mCHERRY and mCITRINE constructs, G. Stier provided plasmid pETM11, Y. Yin provided the BES1 antibody, and the NASC and ABRC provided other materials. Post-doctoral fellowships to Y.J. from the European Molecular Biology Organization, to M.H. from the International Human Frontier Science Program Organization, and from Life Sciences Research Foundation to Y.B. supported this work; Y.J. and M.H. are also supported by the Marc and Eva Stern Foundation. This work was supported by the Howard Hughes Medical Institute and grants from the National Science Foundation (IOS-0649389) (to J.C.) and the National Institutes of Health (1 R01 GM086639) (to E.M.M.). Y.J. performed the plant experiments. M.H. carried out bioinformatics analyses, calorimetry assays and purified proteins. Y.B. provided reagents and purified proteins. T.D. expressed and purified proteins. Z.L.N. carried out bioinformatics analyses and provided reagents. Y.J., M.H., Y.B., Z.L.N., E.M.M., and J.C. analyzed the data. J.C. supervised the work. Y.J., M.H., and J.C. wrote the paper.

\section{References}

Bayliss R, Sardon T, Vernos I, Conti E. 2003. Structural basis of Aurora-A activation by TPX2 at the mitotic spindle. Mol Cell 12: 851-862.

Belkhadir Y, Chory J. 2006. Brassinosteroid signaling: A paradigm for steroid hormone signaling from the cell surface. Science 314: 14101411.

Cock JM, Vanoosthuyse V, Gaude T. 2002. Receptor kinase signalling in plants and animals: Distinct molecular systems with mechanistic similarities. Curr Opin Cell Biol 14: 230-236.

Diella F, Haslam N, Chica C, Budd A, Michael S, Brown NP, Trave G, Gibson TJ. 2008. Understanding eukaryotic linear motifs and their role in cell signaling and regulation. Front Biosci 13: 6580-6603.

Geldner N, Hyman DL, Wang X, Schumacher K, Chory J. 2007. Endosomal signaling of plant steroid receptor kinase BRI1. Genes Dev 21: 1598-1602.

Jaillais Y, Fobis-Loisy I, Miège C, Rollin C, Gaude T. 2006. AtSNX1 defines an endosome for auxin-carrier trafficking in Arabidopsis. Nature 443: 106-109.

Jaillais Y, Santambrogio M, Rozier F, Fobis-Loisy I, Miège C, Gaude T. 2007. The retromer protein VPS29 links cell polarity and organ initiation in plants. Cell 130: 1057-1070.

Kim T-W, Guan S, Sun Y, Deng Z, Tang W, Shang J-X, Sun Y, Burlingame AL, Wang Z-Y. 2009. Brassinosteroid signal transduction from cellsurface receptor kinases to nuclear transcription factors. Nat Cell Biol 11: 1254-1260.

Kuglstatter A, Villaseñor AG, Shaw D, Lee SW, Tsing S, Niu L, Song KW, Barnett JW, Browner MF. 2007. Cutting edge: IL-1 receptor-associated kinase 4 structures reveal novel features and multiple conformations. I Immunol 178: 2641-2645.

Lemmon MA, Schlessinger J. 2010. Cell signaling by receptor tyrosine kinases. Cell 141: 1117-1134.

Lim WA, Pawson T. 2010. Phosphotyrosine signaling: Evolving a new cellular communication system. Cell 142: 661-667.

Manning G, Whyte DB, Martinez R, Hunter T, Sudarsanam S. 2002. The protein kinase complement of the human genome. Science 298: 1912-1934.

Mebratu Y, Tesfaigzi Y. 2009. How ERK1/2 activation controls cell proliferation and cell death: Is subcellular localization the answer? Cell Cycle 8: 1168-1175.

Oh MH, Ray WK, Huber SC, Asara JM, Gage DA, Clouse SD. 2000. Recombinant brassinosteroid insensitive 1 receptor-like kinase autophosphorylates on serine and threonine residues and phosphorylates a conserved peptide motif in vitro. Plant Physiol 124: 751-766.

Oh MH, Wang X, Kota U, Goshe MB, Clouse SD, Huber SC. 2009. Tyrosine phosphorylation of the BRIl receptor kinase emerges as a component of brassinosteroid signaling in Arabidopsis. Proc Natl Acad Sci 106: 658-663.

Oh MH, Wang X, Wu X, Zhao Y, Clouse SD, Huber SC. 2010. Autophosphorylation of Tyr-610 in the receptor kinase BAK1 plays a role in brassinosteroid signaling and basal defense gene expression. Proc Natl Acad Sci 107: 17827-17832.

Sekimata K, Kimura T, Kaneko I, Nakano T, Yoneyama K, Takeuchi Y, Yoshida S, Asami T. 2001. A specific brassinosteroid biosynthesis inhibitor, Brz2001: Evaluation of its effects on Arabidopsis, cress, tobacco, and rice. Planta 213: 716-721.

Shiu SH, Bleecker AB. 2001. Receptor-like kinases from Arabidopsis form a monophyletic gene family related to animal receptor kinases. Proc Natl Acad Sci 98: 10763-10768.

Vert G, Nemhauser JL, Geldner N, Hong F, Chory J. 2005. Molecular mechanisms of steroid hormone signaling in plants. Annu Rev Cell Dev Biol 21: 177-201.

Wang X, Chory J. 2006. Brassinosteroids regulate dissociation of BKIl, a negative regulator of BRI1 signaling, from the plasma membrane. Science 313: 1118-1122.

Wang X, Goshe MB, Soderblom EJ, Phinney BS, Kuchar JA, Li J, Asami T, Yoshida S, Huber SC, Clouse SD. 2005a. Identification and functional analysis of in vivo phosphorylation sites of the Arabidopsis BRASSINOSTEROID-INSENSITIVE1 receptor kinase. Plant Cell 17: 16851703.

Wang X, Li X, Meisenhelder J, Hunter T, Yoshida S, Asami T, Chory J. 2005b. Autoregulation and homodimerization are involved in the activation of the plant steroid receptor BRI1. Dev Cell 8: 855-865.

Wang X, Kota U, He K, Blackburn K, Li J, Goshe MB, Huber SC, Clouse SD. 2008. Sequential transphosphorylation of the BRI1/BAK1 receptor kinase complex impacts early events in brassinosteroid signaling. Dev Cell 15: 220-235.

Xing W, Zou Y, Liu Q, Liu J, Luo X, Huang Q, Chen S, Zhu L, Bi R, Hao Q, et al. 2007. The structural basis for activation of plant immunity by bacterial effector protein AvrPto. Nature 449: 243-247.

Zhang X, Gureasko J, Shen K, Cole PA, Kuriyan J. 2006. An allosteric mechanism for activation of the kinase domain of epidermal growth factor receptor. Cell 125: 1137-1149.

Zhang X, Pickin KA, Bose R, Jura N, Cole PA, Kuriyan J. 2007. Inhibition of the EGF receptor by binding of MIG6 to an activating kinase domain interface. Nature 450: 741-744. 


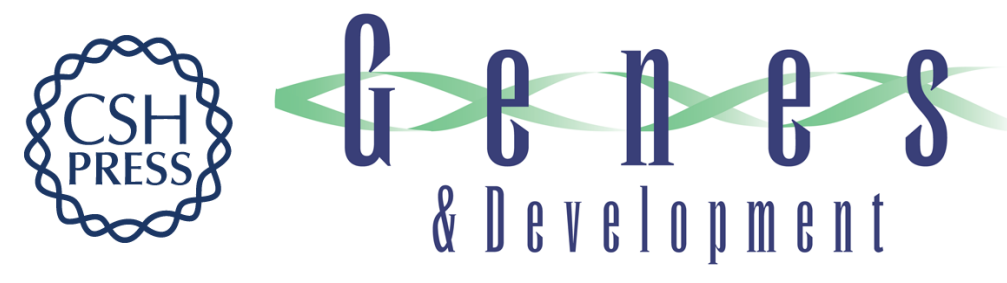

\section{Tyrosine phosphorylation controls brassinosteroid receptor activation by triggering membrane release of its kinase inhibitor}

Yvon Jaillais, Michael Hothorn, Youssef Belkhadir, et al.

Genes Dev. 2011, 25:

Access the most recent version at doi:10.1101/gad.2001911

\section{Supplemental http://genesdev.cshlp.org/content/suppl/2011/02/02/25.3.232.DC1 \\ Material}

Related Content

References

\section{License}

Email Alerting

Service
This article cites 26 articles, 10 of which can be accessed free at: http://genesdev.cshlp.org/content/25/3/232.full.html\#ref-list-1

Articles cited in:

http://genesdev.cshlp.org/content/25/3/232.full.html\#related-urls

Not So Different After All

Annalisa M. VanHook

Sci. Signal. February , 2011 4: ec42

Receive free email alerts when new articles cite this article - sign up in the box at the top right corner of the article or click here.

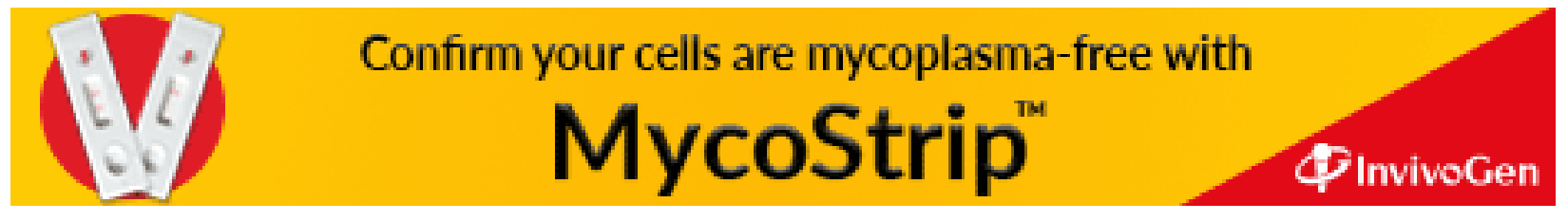

